of regulator, able to ensure the rights of the people. Therefore, we can regard antiquity as the first stage of the emergence of human rights. Through the interpretation of the prominent figures of that period, they laid the cornerstones in the historical construction of the concept. Aristotle's main treatises began to develop the concepts of citizenship and political participation in public affairs, which with evolutionary processes became the basis of the first generation of human rights.

Key words: human rights, state, society, rights and freedoms.

УДК $340.12: 327.39$

DOI https://doi.org/10.32782/2409-4544/2019-2/8

М. Щирба

\title{
Розуміння права на здоров'я у Цілях сталого розвитку
}

У статті проаналізовано положення глобальних Цілей сталого розвитку, які були затверджені у 2015 р. на Саміті ООН зі сталого розвитку. Вони вказують на тенденції розвитку прав людини i визначають основні завдання цивілізованих народів, які повинні бути досягнуті до 2030 року. Здоров'я людини визначається комплексом біологічних (спадкових і набутих) та соціальних факторів. Доведено, що Мета 3 «Забезпечення здорового життя» прирівнюється до права на медичні послуги важливе саме по собі через мету, яка $є$ практичним засобом досягнення поставленого завдання. Також право на охорону здоров'я має стосуватися не лише медичних послуг, а й соціальних та економічних детермінант стану здоров'я. Право на охорону здоров'я включає дві вагомі методологічні складові: не лише право на доступ до медичних послуг, але і соціальні і економічні детермінанти стану здоров'я людини. Аргументовано, що міжнародне співтовариство пріоритетно акцентує увагу виключно на тих елементах, які визначені в Цілі 3, при цьому не допускає широкого тлумачення завдань в сфері охорони здоров'я. Найбільшу увагу в тексті рекомендацій приділено гендерному насильству, здоров'ю матері і дитини, соціально-економічним детерминантам здоров'я, а також системі охорони здоров'я і надання медичних послуг. У той же час питання здоров'я окремих категорій населення (підлітків, представників національних меншин, людей 3 обмеженими можливостями) розкриті досить фрагментарно. Також не всі теми охорони здоров'я отримали однаковий ступінь висвітлення в рекомендаціях ООН. Так, в рекомендаціях достатньо поверхнево висвітлено піходи до профілактики та лікування психічного здоров'я та неінфекційних захворювань.

Ключові слова: право людини, охорона здоров'я, право на здоров'я, медичні послуги, Цілі сталого розвитку.

Постановка наукової проблеми та ії значення. Сучасний світ увійшов в нову епоху правового регулювання інституту прав людини. Для того, щоб зрозуміти сутність прав людини й вказати на тенденції їх розвитку та правового закріплення, на рівні міжнародного погодження були прийняті Глобальні Цілі сталого розвитку (далі - ЦСР), які були затверджені у 2015 році на саміті $\mathrm{OOH}$ з питань сталого розвитку. Перше, що слід зазначити, це те, що «Трансформація нашого світу: порядок денний сталого розвитку до 2030 р.» - резолюція, прийнята Генеральною Асамблеєю ООН, в якій були визначені ЦСР, містить значну кількість прав. Дійсно, в Преамбулі зазначалося, що однією з ключових цілей ЦСР $є$ «реалізація прав усіх людей». Застосовувалися міжнародні документи 3 прав людини, включаючи Загальну декларацію прав людини (пп. 10, 19) та конкретно зазначалося «право на розвиток» (параграфи 10, 35).

Більшість держав світу прийняла цей міжнародний акт в якості державницького напряму розвитку всіх сфер народного господарства. Україна також долучилася до цього процесу, за ініціативи Уряду України та за сприяння інституцій ООН в Україні протягом року тривав відкритий та інклюзивний процес адаптації ЦСР.

Означені цілі включають значну кількість складових, в межах цієї статті акцентуємо увагу на розумінні права на здоров’я у вищезазначеному документі як цінності для народу, держави, особи та майбутніх поколінь.

Аналіз досліджень проблеми. Останнім часом значно зріс інтерес науковців до проблем

() Щирба М., 2019 
правового регулювання сфери охорони здоров'я. Більшість 3 них розглядаються з погляду галузевого правознавства, зокрема новизною відзначаються наукові доробки І. Венедіктова, Д. Гергеля, Н. Мєзєнцевої, С. Стеценко, І. Сенюти, В. Третьякової та ін. Однак питання сфери охорони здоров’я в розумінні міжнародної спільноти залишається актуальним.

Метою цієї статті $\epsilon$ аналіз розуміння права на здоров'я у Цілях сталого розвитку.

Виклад основного матеріалу й обгрунтування отриманих результатів дослідження. Здоров'я людини визначається комплексом біологічних (спадкових і набутих) та соціальних факторів. Останні мають настільки важливе значення в підтримці стану здоров'я або в появі і розвитку хвороби, що у преамбулі статуту Всесвітньої організації охорони здоров'я стверджується, що здоров'я - це стан повного фізичного, духовного і соціального благополуччя, а не тільки відсутність хвороб і фізичних вад.

Варто погодитися з Н. Б. Мєзєнцевою, яка стверджує, що «грунтуючись на факті, що людина $\epsilon$ соціальною істотою, то іiі здоров'я $\epsilon$ соціальною цінністю і передумовою для соціологізації особистості, для іï «обростання» суспільними відносинами, включення в ритм та життя суспільної системи. Здоров'я $є$ мірою соціальної активності, діяльності, ставлення людини до світу. Здоров'я - це одна з необхідних передумов щастя людини, ії всебічного, гармонійного розвитку» [1, с. 101].

Здоров'я населення та окремої людини є вагомим напрямком державного забезпечення. Тому ЦСР визначають цю цінність однією з пріоритетних. Так, Ціль 3 присвячена забезпеченню здорового способу життя та сприяння благополуччя для всіх в будь-якому віці. Зокрема, в ній йдеться про такі вагомі напрямки, які мають бути забезпечені до 2030 року:

- зниження глобального коефіцієнту материнської смертності, смертності новонароджених та дітей до п'яти років;

- зупинення епідемій СНІДу, туберкульозу, малярії та тропічних хвороб, та інших інфекційних захворювань;

- підтримка психічного здоров'я і благополуччя;

- профілактика та лікування залежності від психоактивних речовин;

- зменшення кількості смертей і травм унаслідок дорожньо-транспортних пригод;

- охорона сексуального та репродуктивного здоров'я;

- доступ до якісних основних медико-санітарних послуг а також до безпечних, ефективних, якісних і недорогих основних лікарських засобів і вакцин для всіх;

- скорочення кількості летальних випадків та захворювань в результаті впливу на здоров'я людини небезпечних хімічних речовин, забруднення й отруєння повітря, води і грунтів [2].

Така термінологічна позиція викладена в Цілях знаходить різку критику серед науковців. Вони зазначають, шо мовно Ціль 3 взагалі не містить категорії «право» (крім випадків, пов'язаних 3 правами інтелектуальної власності в 3b). У цьому розумінні Ціль 3 значно «відстає» від деяких інших цілей, в тому числі в галузі освіти (Ціль 4) і гендерної рівності (Ціль 5), де чітко йде мова про права людини.

Л. Форман та ін. справедливо вказують у своїй гіпотезі, що «чітке зосередження на правах людини та праві на здоров'я різко буде суперечити тому, як розглядаються права людини в Цілях розвитку тисячоліття (ЦРТ)» [3, с. 801].

Як зазначали К. Вільямс та Е. Блейлок: «Хоча права людини визнаються в Порядку денному, не існує послідовного, орієнтованого на права, підходу до цілей і завдань. Наприклад, право на здоров'я не містяться ні в тексті, ні в межах жодної цілі. В ЦРТ запропоновані можливості посилення міжнародно-правових зобов'язань 3 прав людини, наприклад, допомогу в розвитку, кліматичні дії або навіть торгові угоди - однак, вони, на жаль, не були прийняті» [4].

Загальна назва Цілі 3 «Забезпечення здорового життя» справді дуже схожа на «здоров'я для всіх». Але це залишається дещо невиразним і декларативним заголовком. Що означає «здорове життя»? I хто несе відповідальність за те, щоб люди мали змогу реалізовувати це право?

Отож, використовуючи метод аналізу, ми можемо прийти до висновку, що Ціль 3 прирівнюється до права на охорону здоров’я і включає дві вагомі методологічні складові:

По-перше, право на доступ до медичних послуг - важлива сама по собі мета, яка є практичним засобом досягнення поставленої цілі.

По-друге, право на охорону здоров'я має стосуватися не лише медичних послуг, а й соціальних та економічних детермінант стану здоров'я. Як стверджували Г. Оомс та колеги: «Для того, щоб право на здоров'я стало реальністю, розробники політики повинні прагнути до здорового фізичного та соціального середовища (наприклад, безпечної питної води та належної санітарії, 
належного харчування та житла, безпечних та здорових професійних та екологічних умов та гендерної рівності)» [5].

Отож, важливо зазначити, що право на охорону здоров'я визначено не тільки в Цілі 3 Глобальних цілей сталого розвитку, а стосуються ще цілого комплексу цілей - Цілі 2 «осягнення подолання голоду, досягнення продовольчої безпеки, поліпшення харчування і сприяння сталого розвитку сільського господарства»; Цілі 6 «Забезпечення наявності і раціонального використання водних ресурсів і санітарії для всіх»; Цілі 11 «Забезпечення відкритості, безпеки, життєстійкості й екологічної стійкості населених пунктів» та інші. Тому зазначимо, що позиція іноземних науковців цілком мотивована. «Деякі елементи, які складають це право, є присутніми та правильними, проте цілі групи розвитку не мають цілісного бачення того, як реально може бути реалізовано «право на здоров'я». Можливо, саме через це визначальне право на здоров'я, не кажучи вже про його реалізацію, завжди залишатиметься недоступним» [6, с. 342].

Вагомо розглянути не тільки нормативне регулювання, але й міжнародні механізми забезпечення права на здоров'я. Універсальний періодичний огляд - один із найбільш широко схвалюваних міжнародних інструментів підзвітності прав людини. Він підтримує просування та захист прав людини і допомагає державам у формуванні їх спроможності захищати та просувати права людини за допомогою технічної допомоги та обміну найкращою практикою.

Створений у 2006 році, цей огляд поступово оцінює записи про права людини кожної держави-члена ООН, включаючи право на здоров'я. У 2017 р. Універсальний періодичний огляд увійшов до свого третього циклу, провівши два повні раунди звітності у 2008-2012 та 2012-2016 роках. Огляд складається з трьох джерел інформації:

1) національного звіту, що надається державою, що перевіряється;

2) збірний звіт інформації ООН про переглянуту державу, підготовлений Управлінням Верховного комісара ООН з прав людини, включаючи інформацію з механізмів ООН $з$ прав людини та іншу офіційну документацію ООН, яка може бути надана агенціями ООН та командами країн;

3) звіт зацікавлених сторін, який узагальнює інформацію, надану іншими суб'єктами, зокрема громадянським суспільством та національними правозахисними установами.

Після обговорення з представниками держави, що переглядається, та представниками усіх 47 членів Ради 3 прав людини, держава, що переглядається, видається 3 рекомендаціями. Держава вказує, які рекомендації підтримує, що сигналізує про прихильність до виконання відповідних вимог а також «зазначає» рекомендації, які вона не підтримує.

Дійсно, Універсальний періодичний огляд має деякі унікальні особливості, які відрізняють огляд від інших механізмів захисту прав людини. На відміну від договірних органів ООН 3 прав людини, які зосереджуються на конкретних правах або групах, таких як люди 3 обмеженими можливостями або жінки, Універсальний періодичний огляд $\epsilon$ всеосяжним, в його рамках аналізується діяльність усіх країн-членів ООН та всі стандарти прав людини незалежно від того, чи держава ратифікувала певний договір. Окрім формально-правових стандартів міжнародного права в галузі прав людини, в огляді також розглядаються добровільні зобов'язання та зобов'язання, взяті державами.

Велика група аналітиків під керівництвом Джудіт Буено де Мескіта проаналізувала всі рекомендації пов'язані зі здоров'ям, розроблені державам-членам під час першого циклу Універсального періодичного огляду, та підрахувала кількість пунктів, що стосуються здоров’я, а також по кожній темі, пов'язаній зі здоров'ям. Використовуючи відносно широку інтерпретацію здоров'я, включаючи багато соціальних та економічних детермінант здоров'я вони виявили, що 3862 $(22 \%)$ iз 17638 пунктів рекомендацій стосуються здоров'я. Зразок огляду рекомендацій, зроблених для географічно різноманітного вибору восьми країн у другому циклі Універсального періодичного огляду (2012-2016) свідчить про те, що рекомендації щодо охорони здоров'я частіше були зроблені протягом цього циклу, як в абсолютній кількості, так і в пропорції всіх рекомендацій. У цих країнах рекомендації щодо охорони здоров'я зросли з 203 до 432 рекомендацій та з 20\% до 26\% від загальної кількості рекомендацій між двома циклами.

У рамках рекомендацій, пов'язаних зі здоров’ям першого циклу, найчастіше згадується гендерне насильство (33\%). Здоров'я матері та дитини було другою за частотою темою загальних проблем, пов'язаних зі здоров'ям (21\%), наступні - соціально-економічні детермінанти здоров'я (13\%) та питання системи охорони здоров'я та послуги (9\%). Однак праву на здоров'я інших груп, таких як підлітки, люди 3 обмеженими можливостями та національні меншини (за деякими винятками, зокрема, ромського населення в Європі), приділено значно меншу увагу [7].

Також не всі теми охорони здоров’я отримали однаковий ступінь висвітлення в 
рекомендаціях. Так, в рекомендаціях відносно знехтувано кількома темами охорони здоров'я, включаючи психічне здоров'я та неінфекційні захворювання, які все більш поширені в сучасному світі. Деякі соціальні детермінанти здоров'я, зокрема, вода, санітарія та харчування, а також доступ до медикаментів рідко згадуються в рекомендаціях.

Висновки. Отож, використовуючи метод аналізу, ми можемо прийти до висновку, що Ціль 3 прирівнюється до права на охорону здоров'я і включає дві вагомі методологічні складові: право на доступ до медичних послуг - - важлива сама по собі мета, яка $є$ практичним засобом досягнення поставленої цілі; право на охорону здоров'я має стосуватися не лише медичних послуг, а й соціальних та економічних детермінант стану здоров'я. Доведено, що міжнародна спільнота акцентує пріоритетно увагу виключно на тих елементах, що визначені у Цілі 3, при цьому не допускаючи широкого тлумачення завдань у сфері охорони здоров'я. При подальшій реалізації Цілей сталого розвитку в найближчі роки варто врахувати специфіку здобутого досвіду, як в контексті досягнень, так і прорахунків, мінімізувати кількість останніх та об'єднувати зусилля науковців, державних діячів, вчених, медиків довкола окреслених проблем задля якомога швидкого та ефективного їх вирішення в інтересах сучасників та в ім'я прийдешніх поколінь.

\section{Джерела та література}

1. Мєзєнцева Н. Б. Право на охорону здоров'я в нормативно-правових актах міжнародного рівня Н. Б. Мєзєнцева // Економіка та держава. - 2011. - № 4. - С. 100-103.

2. Цілі сталого розвитку 2016-2030 [Електронний ресурс]. - Режим доступу: http://www.un.org.ua/ua/tsili-rozvytku-tysiacholittia/tsili-staloho-rozvytku.

3. Forman L., Ooms G., Brolan C. Rights language in the sustainable development agenda: has right to health discourse and norms shaped health goals? // Health Policy Manag. - 2015. - № 4 (12). - P. 799-804.

4. Williams C., Blaiklock A. SDG Series: What Might the SDGs Mean for Health and Human Rights? An Introduction to the Series // Health and Human Rights journal blog. - 2015. - September 1 [Electronic resource]. - Access mode: https://www.hhrjournal.org/2015/09/sdg-series-what-might-the-sdgs-mean-forhealth-and-human-rights-an-introduction-to-the-series.

5. Ooms G., Brolan C., Eggermont N. Universal health coverage anchored in the right to health // Bull. World Health Organ. - 2013. - № 91(1). - P. 2-2A.

6. Rushton S. Health rights and realization: Comment on «Rights language in the sustainable development agenda: has right to health discourse and norms shaped health goals?» // Health Policy Manag. 2016. №5(5). - P. 341-344.

7. Mesquita J., Rebekah T., Gauter C., Havkwist A., Hoddy R. et al. Monitoring the sustainable development goals through human rights accountability reviews // Bull. World Health Organ. - 2018 Sep. 1. - №96(9). - P. 627-633.

Щирба М. Понимание права на здоровье в Целях устойчивого развития. В статье проанализированы положения глобальных Целей устойчивого развития, которые были утверждены в 2015 на саммите ООН по устойчивому развитию. Они указывают на тенденции развития прав человека и определяют основные задачи цивилизованных народов, которые должны быть достигнуты к 2030 году. Здоровье человека определяется комплексом биологических (наследственных и приобретенных) и социальных факторов Доказано, что Цель 3 «Обеспечение здоровой жизни» приравнивается к праву на медицинские услуги - важная сама по себе цель, которая является практическим средством достижения поставленной задачи. Также право на охрану здоровья должно касаться не только медицинских услуг, но и социальных и экономических детерминант состояния здоровья. Право на охрану здоровья включает две весомые методологические составляющие: не только право на доступ к медицинским услугам, но и социальные и экономические детерминанты состояния здоровья человека. Аргументировано, что международное сообщество приоритетно акцентирует внимание исключительно на тех элементах, которые определены в Цели 3, при этом не допускает широкого толкования задач в сфере здравоохранения. Наибольшее внимание в тексте рекомендаций уделено гендерному насилию, здоровью матери и ребенка, социально-экономическим детерминантам здоровья, а также системе здравоохранения и оказания медицинских услуг. В то же время вопрос здоровья отдельных категорий населения (подростков, представителей национальных меньшинств, людей с ограниченными возможностями) раскрыты достаточно фрагментарно. Также не все темы здравоохранения получили одинаковую степень освещения в рекомендациях ООН. В часности, в названых рекомендациях достаточно поверхностно освещены подходы к профилактике и 
лечению психического здоровья и неинфекционных заболеваний.

Ключевые слова: права человека, здравоохранение, право на здоровье, медицинские услуги, Цели устойчивого развития.

Shchyrba M. Interpretation of the Right to Health in the Sustainable Development Goals. The article considers the provisions of the Global Sustainable Development Goals, approved at the 2015 UN Summit on Sustainable Development. They point to the trends in human rights development and identify the main tasks of the civilized nations to be achieved by 2030. Human health determined by a complex biological (hereditary and acquired) and social factors. The author argues that Goal 3 «Ensuring a Healthy Life» equates with the right to health services, an important goal in itself and which is a practical means of achieving the goal, and the right to health care, which includes two important methodological issues: the right of access not only to medical services but also to the social and economic determinants of human health. The right to health care should also apply not only to health services, but also to the social and economic determinants of health. The key finding of the study shows that the international community focuses solely on the elements identified in Goal 3, and does not allow for a broad interpretation of the health care objectives. The issues of gender-based violence, maternal and child health, socio-economic determinants of health, as well as the health care system and the provision of health services are in the focus of the recommendations. Concurrently, the health issues of certain groups of population (adolescents, representatives of national minorities, people with disabilities) are quite fragmented. Also, not all health issues receive the same level of coverage in UN recommendations. In particular, the guidelines relatively neglect several health topics, including mental health and noncommunicable diseases. Goals.

Key words: human rights, health care, right to health, medical services, Sustainable Development 